\title{
Hubungan Motivasi Dan Kemampuan Self Care Terhadap Pengelolaan Nutrisi Serta Cairan Pada Pasien Yang Menjalani Hemodialisis
}

\author{
${ }^{1}$ Rizki Apriyanti \\ ${ }^{2}$ Bayu Saputra \\ ${ }^{3}$ Rani Lisa Indra
}

\begin{abstract}
${ }^{1}$ STIKes Hang Tuah Pekanbaru, Indonesia
${ }^{2}$ STIKes Hang Tuah Pekanbaru, Indonesia

${ }^{3}$ STIKes Hang Tuah Pekanbaru, Indonesia
\end{abstract}

\begin{abstract}
Alamat Korespondensi:
Nama Korespendensi

: Rizki Apriyanti

Bagian/area kepakaran penulis

: Sarjana Keperawatan

Institusi penulis

: STIKes Hang Tuah Pekanbaru

No.Hp / telfn

: 082384880371

Email: penulis

: rizkiapriyanti09@gmail.com
\end{abstract}




\begin{abstract}
ABSTRAK
Pasien gagal ginjal kronis perlu menjalani hemodialisis untuk membuang zat sisa di dalam tubuh. Hal tersebut memaksa pasien untuk mampu melakukan pengelolaan nutrisi dan cairan yang sesuai dengan anjuran yang diberikan oleh tenaga kesehatan, sehingga diperlukan motivasi yang tinggi dan kemampuan self care yang baik untuk mampu melakukan pengelolaan nutrisi dan cairan yang sesuai. Tujuan penelitian ini untuk mengetahui hubungan motivasi dengan pengelolaan nutrisi, hubungan motivasi dengan pengelolaan cairan, hubungan kemampuan self care dengan pengelolaan nutrisi dan kemampuan self care dengan pengelolaan cairan. Pengambilan data dalam penelitian ini menggunakan kuesioner yang sudah dilakukan pengujian validitas dan reliabilitas. Jenis penelitian ini yaitu kuantitatif dengan deskriptif korelasi dengan menggunakan pendekatam cross sectional. Jumlah responden pada penelitian ini berjumlah 74 responden. Pengambilan sampel pada penelitian ini menggunakan teknik non probability sampling dengan metode purposive sampling yaitu mengambil sampel sesuai dengan maksud dan tujuan penelitian. Penelitian ini menggunakan analisis bivariat yaitu uji fisher's exact test. Hasil penelitian ini didapatkan bahwa tidak terdapat hubungan antara motivasi dengan pengelolaan nutrisi dengan nilai $\mathrm{p}=0,816>0,05$, terdapat hubungan antara motivasi dengan pengelolaan cairan dengan nilai $\mathrm{p}=0,036<0,05$, tidak terdapat hubungan antara kemampuan self care dengan pengelolaan nutrisi dengan nilai $\mathrm{p}=0,245>0,05$, dan terdapat hubungan antara kemampuan self care dengan pengelolaan cairan dengan nilai $\mathrm{p}=0,010<0,05$. Hasil penelitian ini dapat dijadikan rekomendasi bagi tenaga kesehatan untuk dapat meningkatkan kepatuhan pasien terhadap pengelolaan nutrisi dan cairan yang sesuai dengan anjuran tenaga kesehatan.
\end{abstract}

Kata Kunci : Gagal Ginjal Kronis, Self Care, motivasi, Cairan, Nutrisi.

\begin{abstract}
A patient with chronic kidney disease has to undergo hemodialysis to rid waste matter in the body. It forces the patient capable to manage the nutrition and fluid by health workers. So need a high motivation and self-care ability for the capability to manage the nutrition and fluid. The aim of the study to determine the relationship between motivation and nutrition management, motivation and fluid management, self-care ability and nutrition management, and self-care ability and fluid management. The measuring instrument used a questionnaire that already testing validity and reliability. The type of research was quantitative with a descriptive correlation and a cross-sectional design. The number of respondents was 74 respondents. The sampling in this study used nonprobability sampling with a purposive method, taken samples according to the aims and objectives of the study. This study used bivariate analysis that was a fisher's test. The results of this study found there was no relationship between motivation and nutrition management with $p$ value $0,816>0,05$, there was relationship between motivation and fluid management with $p$ value $0,036<0,05$, there was no relationship between selfcare ability and nutrition management with $p$ value 0,245>0,05, and there was relationship between self-care ability and fluid management with $p$ value 0,010 < 0,05. This result of the research can be used as a recommendation for the health workers to the improvement of patient adherence about nutrition and fluid management by a recommendation by health.workers.
\end{abstract}

Keywords : Chronic kidney disease, Self Care, Motivation, Fluid, Nutrition. 


\section{PENDAHULUAN}

Gagal ginjal kronis merupakan suatu kerusakan ginjal dengan waktu minimal selama lebih dari tiga bulan. Gagal ginjal kronis ini dapat menyebabkan terjadinya simtoma, dimana simtoma itu sendiri adalah keadaan laju filtrasi glomerulus seseorang berada di bawah rentang 60 $\mathrm{ml} / \mathrm{men} / 1,73 \mathrm{~m}^{2}$ atau nilai yang didapatkan sebaliknya yang disertai dengan tanda dan gejala seperti terjadinya kelainan sedimen urin (Masriadi, 2019).

Secara Internasional menurut World Health Organization (WHO) (2018) jumlah penderita penyakit gagal ginjal kronik diperikarakan sekitar 2 juta penduduk dunia yang terkena penyakit gagal ginjal dan peringkat ini ke-12 sebagai penyebab kematian bagi pengidapnya. Data di Indonesia menurut Riset Kesehatan Dasar (2018) prevalensi penyakit gagal ginjal kronis mengalami peningkatan yaitu dari $2 \%$ pada tahun 2013 menjadi $3,8 \%$ per seribu penduduk ditahun 2018 dan menjadi 3 tertinggi penyakit tidak menular yang terbanyak di Indonesia.

Riau sendiri mengalami peningkatan dimana pada tahun 2013 sekitar $0.18 \%$ per seribu penduduk mengidap gagal ginjal kronis dan pada tahun 2018 jumlahnya menjadi $2,5 \%$ per seribu penduduk yang mengidap penyakit gagal ginjal.
Provinsi Riau khususnya di RSUD Arifin Achmad dalam kurun waktu 2 tahun ini mengalami peningkatan jumlah pasien gagal ginjal kronis yang dimana pada tahun 2018 sebanyak 1.986 orang, 2019 sebanyak 2.572, dan pada tahun 2020 ini didapatkan data 2 bulan terakhir ini sebanyak 576 pasien (Rekam Medis RSUD Arifin Achmad, 2020).

Akibat terjadinya gangguan pada ginjal untuk membuang zat sisa melalui proses eliminasi urin yang dapat menyebabkan gangguan fungsi lain diantarannya fungsi metabolik, endokrin, cairan, elektrolit, dan asam basa sehingga pasien dengan gangguan ginjal perlu untuk melakukan dialisis atau tranplantasi ginjal demi kelangsungan hidupnya (Nurcahyati \& Karim, 2016).

Hemodialisis merupakan metode terapi permanen atau jangka panjang yang digunakan untuk pasien dengan gagal ginjal sebagai terapi pengganti ginjalnya dengan harga terapi yang cukup mahal (Riset Kesehatan Dasar, 2013). Menurut WHO (2018) lebih dari 2 juta penduduk di seluruh dunia menjalani pengobatan dengan hemodialisis maupun transplantasi ginjal, namun jumlah ini hanya mewakili $10 \%$ dari jumlah penderita yang benarbenar membutuhkan pengobatan. Berdasarkan hasil Riset Kesehatan Dasar 
(2018) di Riau sebanyak kurang lebih 22\% penderitanya melakukan terapi hemodialisis. Data di RSUD Arifin Achmad didapatkan bahwa dalam kurun waktu 2 tahun terakhir terdapat sebanyak 1.530 kunjungan pasien yang menjalani hemodialisis. Pasien yang menjalani hemodialisis dalam 2 bulan terakhir sebanyak 90 pasien, dimana setiap bulannya pasien mendapatkan jadwal 2-3 kali untuk menjalani terapi hemodialisis (Rekam Medis RSUD Arifin Achmad, 2020).

Pasien gagal ginjal yang menjalani hemodialisis memiliki risiko terhadap dampak yang dapat timbul jika pasien tidak patuh saat menjalani terapi hemodialisis seperti malnutrisi, masalah cairan di tubuh, hipotensi maupun hipertensi, penumpukan zat-zat berbahaya hasil dari proses metabolisme yang teradi di dalam tubuh (Widiany, 2017). Salah satu cara yang dapat dilakukan untuk mencegah terjadinya hal tersebut, adalah dengan pengelolaan diet. Kini sudah banyak pasien yang lebih sadar bahwa kegagalan dalam menjalani diet dapat berakibat buruk bagi kesehatannya, tetapi sebagian pasien yang menjalani terapi belum mampu melaksanakan maupun mematuhi pembatasan nutrisi dan cairan yang telah dianjurkan (Hermawati,
Hidayati \& Chayati, 2017). Hal ini dapat ditangani dengan adanya peran aktif pasien dengan memberikan motivasi (Sriyati \& Makiyah, 2019).

Motivasi dapat diartikan sebagai sesuatu yang mendorong, pendorong atau pemicu seseorang dalam bertingkah laku demi mencapai maksud dan tujuan (Saam \& Wahyuni, 2012). Menurut Diani dan Choiruna (2019) motivasi ini sangat menentukan hasil akhirnya dimana jika motivasi pasien positif maka hasil yang didapatkan juga positif dan pasien akan melakukan anjuran terapi diet yang sesuai, sedangkan jika motivasi pasien negatif maka hasil yang didapatkan juga negatif dimana asupan cairan akan kurang dan dapat memperburuk keadaan pasien tersebut. Motivasi ini sendiri erat kaitannya dengan kemampuan self care pasien dalam mengelola dietnya.

Kemampuan self care pada pasien dengan gagal ginjal kronis saat ini menjadi perhatian di dunia, karena terus berkembangnya penyakit kronis pada abad ini. Setiap individu mempunyai kemampuan untuk merawat kesehatan diri sendiri. Menurut Riegel, Jaarsma dan Strömberg (2018) proses yang mendasari self care adalah pengambilan keputusan rasional yang dibuat oleh pasien yang meliputi pemilihan tingkah laku yang 
bertujuan untuk mempertahankan keadaan fisiologis tubuhnya (maintenance) serta keyakinan pasien terhadap upaya self care yang telah dilakukannya (confidence).

Berdasarkan hasil studi pendahuluan yang dilakukan peneliti dengan mewawancarai 5 pasien, peneliti memberikan pertanyaan terbuka. Didapatkan bahwa 3 pasien yang melakukan hemodialisis memahami dampak yang akan timbul jika melakukan hemodialisis dengan tidak mengimbangi pengelolaan nutrisi dan cairan. Pengelolaan nutrisi yang dilakukan pasien yaitu dengan mengurangi jumlah natrium dan mengurangi makanan tinggi lemak, dan menghindari belimbing, dan pengelolaan cairan yaitu pasien mengkonsumsi 500 $\mathrm{ml} /$ hari selama masa terapi ini. Sedangkan pada 2 pasien lainnya mengatakan bahwa mereka melakukan terapi hemodialisis karena merasa terapi tersebut membuatnya lebih baik dan dapat mengurangi hal buruk seperti terjadinya komplikasi dari penyakit ini, tetapi 2 pasien tersebut tidak mengikuti anjuran yang seharusnya dilakukan dalam terapi hemodialisis. 2 pasien tersebut mengatakan masih mengkonsumsi makanan yang tinggi protein, natrium, lemak serta asupan cairan yang dikonsumsi juga masih melebihi yang telah dianjurkan. Pasien merasa malas untuk melakukan pengelolaan nutrisi dan cairan karena merepotkan, serta menganggap bahwa kebiasaan yang telah dilakukan saat ini tidak berpengaruh apapun terhadap tubuhnya.

Berdasarkan uraian di atas serta data yang dipaparkan menunjukkan bahwa penyakit gagal ginjal ini terus bertambah seiring berjalannya waktu, dan hasil studi pendahuluan menunjukkan bahwa pasien yang melakukan terapi hemodialisis harus melakukan diet cairan dan nutrisi yang harus dijalani seumur hidup masih belum dilakukan dengan maksimal oleh pasien sehingga peneliti tertarik untuk meneliti hubungan antara motivasi dan self care terhadap pengelolaan nutrisi serta cairan pasien yang menjalani hemodialisis.

\section{METODE}

Jenis penelitian ini adalalah kuantitatif dengan deskriptif korelasi dengan pendeFkatan cross sectional. Populasi pada penelitian ini adalah pasien yang menjalani hemodialisis di RSUD Arifin Achmad Provinsi Riau tahun 2020 yakni sebanyak 90 orang. Teknik sampling yang digunakan pada penelitian ini adalah metode non probability sampling (purposive sampling), sampel yang didapatkan pada penelitian ini yaitu sebanyak 74 responden. Instrumen pengukuran pada penelitian ini dengan 
menggunakan lembar kuesioner untuk setiap variabel yang diteliti.

Data yang telah dikumpulkan kemudian diolah dan dilakukan analisis dengan menggunakan uji fisher's exact test dengan syarat tidak memiliki nilai expectation tabel $<5 \%$, dengan menggunakan tabel $2 \times 2$. Analisis ini menggunakan bantuan kerja komputer.

\section{HASIL}

Berdasarkan tabel 1 didapatkan data bahwa usia pasien yang menjalani hemodialisis di RSUD Arifin Achmad adalah usia 54 tahun, Rata-rata lama waktu pasien yang menjalani hemodialisis di RSUD Arifin Achmad adalah 20 bulan.

Berdasarkan tabel 2 pasien yang menjalani hemodialisis mayoritas berjenis kelamin laki-laki lebih banyak yaitu berjumlah 38 orang (51.4\%). Tingkat pendidikan pasien yang menjalani hemodialisis mayoritas adalah SMA sebanyak 35 orang $(47.3 \%)$.

Berdasarkan hasil tabel 3 menunjukkan bahwa pasien yang memiliki motivasi yang tinggi sama dengan motivasi yang rendah yaitu sebanyak 37 (50\%). Pasien yang memiliki kemampuan self care yang baik sama dengan motivasi yang kurang baik yaitu sebanyak 37 (50\%). Mayoritas pasien yang memiliki pengelolaan nutrisi yang baik yaitu sebanyak 38 orang pasien (51.4\%) .Pasien yang menjalani hemodialisis memiliki pengelolaan cairan yang baik dengan hasil sebanyak 38 orang pasien (51.4\%).

Berdasarkan tabel 4 dapat dilihat bahwa $p$ value $0,816>0,05$, hal ini berarti menunjukan tidak terdapat hubungan antara motivasi dengan pengelolaan nutrisi. terdapat hubungan antara motivasi dengan pengelolaan nutrisi $0,036<0,05$, tidak terdapat hubungan antara kemampuan self caredengan pengelolaan nutrisi 0,245, terdapat hubungan antara kemampuan self care dengan pengelolaan cairan $0,010<$ 0,05 .

\section{PEMBAHASAN}

\section{Hubungan Motivasi dengan Pengelolaan} Nutrisi

Dari hasil penelitian yang dilakukan di RSUD Arifin Achmad Provinsi Riau diperoleh hasil uji statistik yang dilakukan menggunakan uji fisher's exact test diperoleh $p$ value yaitu 0,816 . Dengan demikian $p$ value $>\alpha(0,05)$ berarti menujukkan bahwa tidak ada hubungan yang signifikan antara motivasi dengan pengelolaan nutrisi pasien yang menjalani hemodialisis.

Berdasarkan analisis peneliti juga didapatkan data bahwa sebanyak 37 orang pasien yang memiliki motivasi tinggi yaitu 20 orang pasien dengan motivasi tinggi 
dan dalam melakukan pengelolaan nutrisi yang baik, 17 orang pasien yang memiliki motivasi tinggi tetapi dalam melakukan pengelolaan nutrisi yang kurang baik dan 37 orang lainnya yang memiliki motivasi rendah yaitu 18 orang yang meiliki motivasi rendah tetapi melakukan pengelolaan nutrisi dengan baik dan 19 orang lainnya memiliki motivasi rendah dan dalam melakukan pengelolaan nutrisi juga kurang baik. Hasil ini sejalan dengan penelitian yang dilakukan yang dilakukan oleh Ismail, Hasanuddin dan Bahar (2012) yang menyatakan bahwa terdapat hubungan yang bermakna antara motivasi dengan kepatuhan diet pada pasien yang menjalani hemodialisis.

Motivasi merupakan suatu bentuk dorongan yang ada di dalam diri setiap individu yang nantinya diwujudkan dalam bentuk tindakan maupun caranya berperilaku terhadap pengelolaan nutrisi gagal ginjal kronis yang telah diberikan oleh tenaga kesehatan (Balulu, Paratmanitya dan Nabil, 2016). Menurut Notoatmodjo (2010) motivasi akan selalu berkaitan dengan kebutuhan atau need and want. Sebagaimana kita ketahui bahwa kebutuhan merupakan sesuatu hal yang terdapat di dalam diri manusia yang perlu direspon ataupun ditanggapi. Hal ini berbanding terbalik dengan hasil penelitian yang didapat bahwa pasien yang memiliki motivasi tinggipun tidak dapat menentukan apakah pasien mampu untuk melaksanakan pengelolaan nutrisi dengan baik ataupun tidak, sehingga peneliti beranggapan bahwa peran petugas sangat diharapkan untuk dapat membantu pasien dalam melakukan pengelolaan nutrisi yang baik demi mencegah terjadinya masalah klinis yang lain.

Menurut Syamsiah (2011) motivasi merupakan faktor yang mempengaruhi seseorang dalam melakukan pengelolaan nutrisi dan cairan. Motivasi merupakan suatu proses psikologikal yang dapat menyebabkan terjadinya tingkah laku yang sesuai dengan yang diharapkan. Hal ini tidak sejalan dengan penelitian yang didapatkan bahwa pasien yang memiliki motivasi yang tinggi tetapi dalam melaksanakan pengelolaan cairan masih kurang baik.

Berdasarkan uraian di atas maka dapat disimpulkan bahwa motivasi bukanlah satu-satunya faktor yang dapat mempengaruhi pasien dalam melaksanakan pengelolaan nutrisi dengan baik, terdapat faktor lain seperti usia, jenis kelamin, tingkat pendidikan dan lama menjalani hemodialisis. Sehingga diharapkan perlu adanya penelitian lain yang membahas mengenai faktor-faktor yang dapat 
mempengaruhi pengelolaan nutrisi pada pasien.

\section{Hubungan Motivasi dengan Pengelolaan}

\section{Cairan}

Berdasarkan hasil uji yang dilakukan dengan menggunakan uji fisher's exact test diperoleh $p$ value yaitu 0,036. Dengan demikian $p$ value $<\alpha(0,05)$ berarti menunjukkan bahwa terdapat hubungan antara motivasi dengan pengelolaan cairan pasien yang menjalani hemodialisis. Penelitian ini sejalan dengan penelitian yang dilakukan oleh Nadi, Kurniawati dan Maryanti (2015), mengatakan bahwa terdapat hubungan antara motivasi dengan kepatuhan pembatasan asupan cairan pada pasien yang menjalani hemodialisis. Semakin tinggi motivasi maka semakin patuh pasien dalam pembatasan cairannya.

Pengelolaan cairan ini dipengaruhi oleh beberapa faktor salah satunya merupakan motivasi. Menurut Pramesti (2016) motivasi merupakan suatu dorongan yang mendasari seseorang untuk memenuhi kebutuhannya. Sebagaimana kita ketahui bahwa kebutuhan merupakan sesuatu hal yang terdapat di dalam diri manusia yang perlu direspon ataupun ditanggapi. Hal ini juga dengan penelitian yang dilakukan oleh Dani, Utami dan Bayhakki (2015) yang memaparkan bahwa terdapatnya hubungan yang signifikan antara motivasi dengan kepatuhan pasien gagal ginjal kronis yang menjalani hemodialisis.

Menurut Perhimpunan Nefrologi Indonesia (2019) pasien gagal ginjal kronis yang menjalani hemodialisis dianjurkan hanya mengkonsumsi cairan sebanyak 500 $\mathrm{ml} /$ hari. Perlu pengelolaan cairan yang ketat untuk pasien yang menjalani hemodialisis, kebutuhan cairan pasien dengan hemodialisis ini lebih rendah dari biasanya (Isroin, 2016). Sehingga pasien yang menjalani hemodialisis perlu untuk mengatur dietnya dan perlu untuk memiliki motivasi yang tinggi. Semakin tinggi motivasi pasien maka akan cenderung berperilaku lebih patuh dibandingkan dengan yang memiliki motivasi rendah karena motivasi adalah salah satu kondisi yang dapat menggerakkan perilaku atau mengarahkan seseorang dalam melakukan aktivitasnya (Dani, Utami \& Bayhakki, 2015).

\section{Hubungan Kemampuan Self Care dengan Pengelolaan Nutrisi}

Hasil penelitian ini, memperoleh $p$ value yaitu 0,245. Dengan deminikan $p$ value $>\alpha(0,05)$ berarti menujukkan bahwa tidak ada hubungan yang signifikan antara kemampuan self care dengan pengelolaan nutrisi pasien yang menjalani hemodialisis. Hasil penelitian ini juga menunjukkan 
bahwa sebanyak 22 orang pasien memiliki kemampuan self care dalam melakukan pengelolaan nutrisi yang baik, 15 orang pasien yang memiliki kemampuan self care yang baik dalam melakukan pengelolaan nutrisi kurang baik. 37 orang lainnya yang masuk ke dalam kategori kemampuan self care kurang baik yaitu; 16 orang pasien memiliki kemampuan self care kurang baik tetapi dalam melakukan pengelolaan nutrisi baik, dan 21 orang memiliki kemampuan self care kurang baik dan dalam melakukan pengelolaan nutrisi kurang baik. Penelitian ini tidak sejalan dengan penelitian yang dilakukan oleh Hermawati, Hidayati dan Chayati (2017) yang menyatakan bahwa terdapat hubungan antara self care dengan status nutrisi pasien dengan hasil yang menunjukkan bahwa semakin baik self care yang dimiliki pasien maka makan semakin meningkatkan status nutrisi dari pasien.

Hasil penelitian yang dilakukan oleh Hidayati dan Wahyuni (2012) menunjukkan bahwa pemahaman serta kesadaran dan atas kemauan sendiri atas hal yang dilakukan pasien demi memenuhi kebutuhan self care secara optimal. Pasien dapat melakukan kegiatan pemenuhan self care nya dengan cara mengkontrol keseimbangan cairan dan nutrisi di dalam tubuhnya. Hal ini bertentangan dengan penelitian yang dilakukan oleh peneliti saat ini yang mana tidak terdapat adanya hubungan antara kemampuan self care dengan pengelolaan nutrisi.

Suparti dan Kurniawan (2015) mengatakan bahwa management pembatasan makanan pada pasien gagal ginjal yang menjalani hemodialisis merupakan sebuah aspek penting dari self care management karena dengan melakukan pembatasan makanan dapat mempertahankan status gizi dan elektrolit pasien. Namun, hal ini justru sebaliknya sebanyak 37 orang pasien masih memiliki kemampuan self care kurang baik.

Menurut peneliti yang memiliki kemampuan self care yang baik seharusnya mampu melakukan pengelolaan nutrisi yang baik. Namun sebaliknya di dalam penelitian ini penelitian menemukan bahwa kemampuan self care tidak menjamin bahwa pasien mampu melakukan pengelolaan nutrisi dengan baik. Hal ini terjadi karena banyak faktor dapat mempengaruhi seperti usia, jenis kelamin, tingkat pendidikan, lama menjalani hemodialisis.

\section{Hubungan Kemampuan Self Care dengan Pengelolaan Cairan \\ Hasil penelitian ini juga mendapatkan bahwa terdapat ada}


hubungan yang signifikan antara kemampuan self care dengan pengelolaan cairan pasien yang menjalani hemodialisis dengan nilai $p$ value yaitu 0,010 sehingga $p$ value $<\alpha(0,05)$ bahwa terdapat hubungan antara kemampuan self care dengan pengelolaan cairan. Hasil penelitian ini sejalan dengan Nurcahyati dan Karim (2016) yang melakukan implementasi self care terhadap responden yang diteliti, bahwa terdapat hubungan antara pembatasan cairan yang dapat dipengaruhi oleh kondisi lingkungan yang panas sehingga menyebabkan rasa haus terus menerus dan kurangnya dukungan keluarga dalam penyediaan diet yang sesuai.

Hasil penelitian ini juga mendapatkan bahwa pasien yang memiliki kemampuan self care dan pengelolaan cairan dalam kategori kurang sebanyak 24 orang pasien (18\%). Hal ini sejalan dengan penelitian yang dilakukan oleh Kim dan Evangelista (2010) yang mendapatkan bahwa $62 \%$ respondennya kesulitan dalam menerapkan pembatasan cairan, hal ini dikarenakan pasien belum mampu untuk mengontrol diri atas keinginan minum dan rasa haus yang tidak tertahankan. Pasien lebih memilih untuk meminum air putih yang seharusnya dapat digantikan dengan menyedot ataupun menghisap es batu. Hal ini didukung dengan penelitian yang dilakukan oleh Fahmi dan Hidayati (2016) mengungkapkan bahwa kemampuan self care dalam pengelolaan cairan masih belum maksimal yang dilakukan oleh pasien gagal ginjal kronis yang menjalani hemodialisis.

Hasil penelitian ini juga menunjukkan bahwa pasien yang memiliki kemampuan self care yang baik tetapi pengelolaan cairan kurang baik ini dipengaruhi oleh banyak faktor seperti usia, jenis kelamin, tingkat pendidikan, lama menjalani hemodialisis.

\section{KESIMPULAN DAN SARAN}

Berdasarkan hasil penelitian maka dapat disimpulkan bahwa tidak terdapat hubungan yang signifikan antara motivasi dengan pengelolaan nutrisi. Terdapat hubungan yang signifikan antara motivasi dengan pengelolaan cairan yang menjalani hemodialisis di RSUD Arifin Achmad Provinsi Riau. Tidak terdapat hubungan yang signifikan antara kemampuan self care dengan pengelolaan nutrisi pasien yang menjalani hemodialisis di RSUD Arifin Achmad Provinsi Riau, dan terdapat hubungan yang signifikan antara kemampuan self care dengan pengelolaan cairan yang menjalani hemodialisis di RSUD Arifin Achmad Provinsi Riau. Hal ini tidak sesuai dengan teori yang 
mengatakan bahwa pengelolaan nutrisi dan cairan dipengaruhi oleh usia, jenis kelamin, motivasi, dukungan keluarga, lama menjalani hemodialisis, pendidikan, pendapatan dan persepsi pasien terhadap pelayanan kesehatan.

Menurut peneliti pengelolaan nutrisi dan cairan bukan hanya dipengaruhi oleh motivasi maupun kemampuan self care tetapi terdapat faktor lain yang dapat mempengaruhinya seperti usia dimana pada penelitian ini peneliti mendapatkan rentang usia yang cukup jauh sehingga pemahamannya mengenai pengelolaan nutrisi dan cairan pasti akan berbeda. Faktor lain yang mungkin dapat mempengaruhi yaitu pendidikan seseorang dimana pendidikan merupakan faktor penentu kualitas seseorang dalam pemahamannya.

Penelitian ini mendapatkan bahwa masih terdapat pasien yang hanya bersekolah SD ataupun tidak bersekolah, sehingga hal ini dapat mempengaruhi pasien dalam melakukan pengelolaan nutrisi dan cairannya. Adapun saran bagi institusi tempat penelitian, penelitian ini diharapkan bisa membuat institusi tempat penelitian khususnya unit hemodialisis RSUD Arifin Achmad untuk meningkatkan dan memperhatikan serta memberikan informasi terkait pentingnya pengelolaan nutrisi serta cairan pada pasien yang menjalani hemodialisis.

Hal tersebut dapat diterapkan dengan memberikan informasi dengan menggunakan media seperti lembar balik maupun media cetak yang lain agar informasi lebih mudah diserap dan dipahami oleh pasien dan diharapkan hal tersebut dapat meningkatkan pengelolaan nutrisi dan cairan pasien. Sedangkan bagi pasien Penelitian ini diharapkan dapat menambah wawasan kepada masyarakat luas, serta sebagai bahan evaluasi dalam meningkatkan keterampilan dan kemampuan self care pasien dalam pelaksanaan pengelolaan nutrisi dan cairan pada pasien yang menjalani hemodialisis.

\section{DAFTAR PUSTAKA}

Dani, R., Utami, G. T., \& Bayhakki. (2015). Hubungan motivasi, harapan, dan dukungan petugas kesehatan terhadap kepatuhan pasien gagal ginjal kronik untuk menjalani hemodialisis. Jom, 2(2), 1362-1371. https://media.neliti.com/media/public ations/184149-ID-hubunganmotivasi-harapan-dan-dukungan-p.pdf Dasar, R. K. (2013). Penyajian pokokpokok hasil riset kesehatan dasar 2013.

Diani, N., \& Choiruna, H. P. (2019). 
Hubungan motivasi dan kepercayaan dengan kepatuhan pembatasan cairan pada pasien hemodialisis ( the relationship between motivation and trust with the non-adherence of restriction liquid toward hemodialysis patient ). 3(2), 38-45. http://journal.umbjm.ac.id/index.php/ caring-nursing/article/view/239/271

Fahmi, F. Y., \& Hidayati, T. (2016). Gambaran self care status cairan pada pasien hemodialisa ( Literatur Review ). Care: Jurnal Ilmiah Ilmu Kesehatan, 4(2), 53-63.

Hidayati, W., \& Wahyuni, K. (2012). Pengalaman self-care berdasarkan teori orem pada pasien penyakit ginjal kronik yang menjalani hemodialisis. Jurnal Nursing Studies, 1(1), 244251.

Ismail., Hasanudin., \& Bahar. (2012). Hubungan pendidikan, pengetahuan dan motivasi dengan kepatuhan diet pada pasien gagal ginjal kronik di rumah sakit umum daerah kardinah tegal.

Isroin, L. (2016). Manajemen cairan pada pasien hemodialisis untuk meningkatkan kualitas hidup. Ponorogo: Perpustakaan Nasional : Katalog Dalam Terbitan (KDT).
Kim, Y., \& Evangelista, L. S.. (2010). Relationship between illness perceptions, treatment adherence, and clinical outcomes in patients on maintanance hemodialysis. Nephrology nursing journal. Vol 37 (3).

Masriadi. (2019). Epidemiologi penyakit tidak menular. Jakarta Timur: CV. Trans Info Media.

Nadi, H. I. K., Kurniawati, N. D., \& Maryanti, H. (2015). Dukungan ginjal kronik yang menjalani hemodialisis. Jurnal Universitas Airlangga, 3(2), $1-7$.

Notoatmodjo, S. (2010). Promosi kesehatan dan perilaku kesehatan. Jakarta: Rineka Cipta.

Nurcahyati, S., \& Karim, D. (2016). Implementasi Self Care Model dalam Upaya Meningkatkan Kualitas Hidup Penderita Gagal Ginjal Kronik. Jurnal Keperawatan Sriwijaya, 3(2), 25-32.

Rekam Medis RSUD Arifin Achmad. (2020). Jumlah penderita gagal ginjal di RSUD Arifin

Achmad. Tidak dipublikasikan.

Rekam Medis RSUD Arifin Achmad. (2020). Jumlah kunjungan pasien gagalginjal yang menjalani hemodialisis di RSUD Arifin Achmad. Tidak dipublikasikan. 
Riegel, B., Jaarsma, T., \& Stromberg, A. (2018). Theory of self-care of chronic illness. Middle Range Theory for Nursing, Fourth Edition, 35, 341353.

https://doi.org/10.1891/97808261599 22.0016

Riskesdas, K. (2018). Hasil Utama Riset

Kesehatan Dasar (RISKESDAS). Journal of Physics A: Mathematical and Theoretical, 44(8), 1-200. https://doi.org/10.1088/1751$8113 / 44 / 8 / 085201$

Saam, Z., \& Wahyuni, S. (2012). Psikologi keperawatan. Jakarta: PT. Raja Grafindo Persada.

Sriyati., \& Makiyah, N. (2019). Pembatasan Cairan Pasien Yang Menjalani Hemodialisis Latar Belakang Chronic Kidney Disease ( $C K D$ ) Mengalami Peningkatan Secara Global, Dan Penyakit Ini Mempengaruhi Sekitar $10 \%$ Populasi Orang Meningkatnya Diabetes Melitus , Hipertensi Dan Obesitas Telah.

Suparti, S., \& Kurniawan, T. (2015). Self Management Program Pada Pasien Hemodialisis. Portal Garuda: Journal Medisains. Vol 14 (1).
Purwokerto: Universitas Muhammadiyah:Purwokerto.http:// edisains.ump.ac.id/index.php/medis ins/artie/view/26.

Syamsiah, 2011. (2011). Faktor-faktor yang berhubungan dengan kepatuhan pasien ckd yang menjalani hemodialisa di rspau dr esnawan antariksa halim perdana kusuma jakarta. Jurnal Visikes, 10(2), 115123.

Widiany, F. L. (2017). Faktor-faktor yang mempengaruhi kepatuhan diet pasien hemodialisis. Jurnal Gizi Klinik Indonesia, $\quad$ 14(2), 72. https://doi.org/10.22146/ijcn.22015

World Health Organization (WHO). (2018 the global burden of kidney disease and the sustainable development goals. Vol $96 \quad 414$ 422D).https://www.who.int/b ulletin/volumes/96/6/1

2016441/en/. 
Tabel 1.Distribusi Frekuensi Usia dan Lama Menjalani Hemodialisis Responden di RSUD Arifin Achmad Provinsi Riau

\begin{tabular}{ccccc}
\hline Usia & Mean & Median & Std. Deviation & Min-max \\
\cline { 2 - 5 } & 52.51 & 54.00 & 9.045 & $15-71$ \\
\cline { 2 - 5 } Lama Menjalani & 22.42 & 19.50 & 16.505 & $3-90$ \\
Hemodialisis & & & &
\end{tabular}

Tabel 2. Distribusi Frekuensi Jenis Kelamin dan Tingkat Pendidikan Responden di RSUD Arifin Achmad Provinsi Riau

\begin{tabular}{ccc}
\hline Karakteristik responden & frekuensi $(f)$ & Persentase $(\%)$ \\
\hline Jenis Kelamin & & \\
Laki-laki & 38 & 51.4 \\
Perempuan & 36 & 48.6 \\
\hline Tingkat Pendidikan & & \\
SD & 4 & 5.4 \\
SMP & 18 & 24.3 \\
SMA & 35 & 47.3 \\
Sarjana & 13 & 17.6 \\
Tidak Bersekolah & 4 & 54 \\
\hline Total & 74 & 100.0
\end{tabular}

Tabel 3.Distribusi Frekuensi Motivasi, Kemampuan Self Care, Pengelolaan Nutrisi, dan Pengelolaan Cairan

\begin{tabular}{ccc}
\hline Motivasi & frekuensi $(\boldsymbol{f})$ & Persentase (\%) \\
\hline Tinggi & 37 & 50.0 \\
Rendah & 37 & 50.0 \\
\hline Total & 74 & 100.0 \\
\hline Kemampuan Self Care & frekuensi $(\boldsymbol{f})$ & Persentase $(\boldsymbol{\%})$ \\
\hline Baik & 37 & 50.0 \\
\hline Kurang & 37 & 50.0 \\
\hline Total & 74 & 100.0 \\
\hline Pengelolaan Nutrisi & frekuensi $(\boldsymbol{f})$ & Persentase $(\boldsymbol{\%})$ \\
\hline Baik & 38 & 51.4 \\
\hline Kurang & 36 & 48.6 \\
\hline Total & 74 & 100.0 \\
\hline Pengelolaan Cairan & frekuensi $(\boldsymbol{f})$ & Persentase $(\boldsymbol{\%})$ \\
\hline Baik & 38 & 51.4 \\
\hline Kurang & 36 & 48.6 \\
\hline Total & 74 & 100.0
\end{tabular}


Tabel 4. Hubungan Motivasi dengan Pengelolaan Nutrisi dan Pengelolaan Cairan Hubungan Kemampuan Self Care dengan Pengelolaan Nutrisi dan Cairan

\begin{tabular}{|c|c|c|c|c|c|}
\hline \multicolumn{4}{|c|}{ Pengelolaan Nutrisi } & \multirow[t]{2}{*}{ Total } & \multirow[t]{2}{*}{ P value } \\
\hline \multirow[t]{3}{*}{ Motivasi } & & Baik & Kurang & & \\
\hline & Tinggi & $20(54.1 \%)$ & $17(45.9 \%)$ & $37(100.0 \%)$ & \multirow{3}{*}{0,816} \\
\hline & Rendah & $18(48.6 \%)$ & $19(51.4 \%)$ & $37(100.0 \%)$ & \\
\hline \multicolumn{2}{|c|}{ Total } & $38(51.4 \%)$ & $36(48.6 \%)$ & $74(100.0 \%)$ & \\
\hline \multicolumn{4}{|c|}{ Pengelolaan Cairan } & Total & P value \\
\hline \multirow[t]{3}{*}{ Motivasi } & & Baik & Kurang & & \\
\hline & Tinggi & $24(64.9 \%)$ & $13(35.1 \%)$ & $37(100.0 \%)$ & 0,036 \\
\hline & Rendah & $14(37.8 \%)$ & $23(62.2 \%)$ & $37(100.0 \%)$ & \\
\hline \multicolumn{2}{|c|}{ Total } & $38(51.4 \%)$ & $36(48.6 \%)$ & $74(100.0 \%)$ & \\
\hline & \multicolumn{3}{|c|}{ Pengelolaan Nutrisi } & Total & Pvalue \\
\hline \multirow{3}{*}{$\begin{array}{c}\text { Kemampuan } \\
\text { Self Care }\end{array}$} & & Baik & Kurang & & \\
\hline & Baik & $22(59.5 \%)$ & $15(40.5 \%)$ & $37(100.0 \%)$ & 0,245 \\
\hline & Kurang & $16(43.2 \%)$ & $21(56.8 \%)$ & $37(100.0 \%)$ & \\
\hline \multirow[t]{2}{*}{ Total } & & $38(51.4 \%)$ & $36(48.6 \%)$ & $74(100.0 \%)$ & \\
\hline & \multicolumn{3}{|c|}{ Pengelolaan Cairan } & Total & P value \\
\hline \multirow{3}{*}{$\begin{array}{c}\text { Kemampuan } \\
\text { Self Care }\end{array}$} & & Baik & Kurang & & \\
\hline & Baik & $25(67.6 \%)$ & $12(32.4 \%)$ & $37(100.0 \%)$ & 0,10 \\
\hline & Kurang & $13(35.1 \%)$ & $24(64.9 \%)$ & $37(100.0 \%)$ & \\
\hline \multicolumn{2}{|c|}{ Total } & $38(51.4 \%)$ & $36(48.6 \%)$ & $74(100.0 \%)$ & \\
\hline
\end{tabular}

